\title{
CGNL1 Gene
}

National Cancer Institute

\section{Source}

National Cancer Institute. CGNL1 Gene. NCI Thesaurus. Code C98064.

This gene plays a role in tight junction org anization. 